\title{
EFFECTIVENESS TEST OF NEEM GUM (Azadirachta indica) SOLUTION AGAINST THE VIABILITY OF Escherichia coli AND Salmonella Typhimurium (IN VITRO)
}

\author{
Debi Suntari ${ }^{1}$, Dominica Diana Siswadi ${ }^{{ }^{*}}$, Zahreni Hamzah², Ari Tri Wanodyo Handayani ${ }^{3}$, \\ Dyah Indartin Setyowati ${ }^{4}$ \\ 1) Faculty of Dentistry, University of Jember, East Java , Indonesia \\ 2) Department of Biomedical, Faculty of Dentistry, University of Jember, East Java , \\ Indonesia \\ 3) Department of Dental Public Health, Hospital Dental Service, Faculty of Dentistry, \\ University of Jember, East Java, Indonesia \\ 4) Department of Oral diseases, Hospital Dental Service, Faculty of Dentistry, University of \\ Jember, East Java, Indonesia \\ Correspondence author, email: dominicadianas@gmail.com
}

\begin{abstract}
Neem gum is an exudate from hardened neem plant (Azadirachta indica). Neem gum contains many active compounds especially heteropolysaccharides. It composes monosaccharides namely L-arabinose, L-fucose, D-galactose, D-glucuronic acid, $D$-xylose, glucose, and mannose. In addition, there are other compounds of neem gum such as $\mathrm{NaCl}$, $\mathrm{KCl}$, salvadora, salvadorin, saponin, phenol, and tannin have the potential to reduce the viability of pathogens. Heteropolysaccharides are water soluble non-starch carbohydrates. Heteropolysaccharides are known unable to be degraded by digestive enzymes but have potential as substrates for commensal bacteria that can benefit the host. One of the requirements for functional food ingredient is also to reduce the viability of pathogenic bacteria such as Escherecia coli and Salmonella Typhimurium. The MTT test method was used to calculate bacterial viability. The viability of two bacteria exposed to neem gum solution decreased as the concentration increased, according to the results of this study.
\end{abstract}

Keywords: Escherichia coli, MTT assay, Neem Gum, Salmonella Typhimurium, Viability

\section{INTRODUCTION}

According to its last name "indica", Neem (Azadirachta indica) is a plant originating from India (Kumar and Navaratnam, 2013). Since ten thousand years ago, neem has been used as a traditional medicine by the Indian who consider it as a magic tree. This plant is spread in South Asia and Southeast Asia such as Sri Lanka, Malaysia, Pakistan, Thailand, and Indonesia (Pankaj et al., 2011). Neem in Indonesia is spread across Java, Madura, Bali, and Lombok (Prianto et al., 2019). It is easy to find on the roadside because it is not difficult to reproduce sexually or vegetatively. However, this plant is often considered a nuisance weed. This plant produces abundant gum through the gumming syndrome event. Unfortunately, gum has not been widely used by local communities in Indonesia (Nussinovitch, 2010).

Neem gum has the potential to be used as functional food that improving our health by supressed the pathogenic bacteria. Neem gum contains of non-starch heteropolysaccharides with many branching chains of monosaccharides such as L-arabinose, L-fucose, D-galactose, D-glucuronic acid, D-xylose, glucose, and mannose (Nussinovitch, 2010; Moniem et al., 2018). Neem gum also contains other bioactive compounds such as $\mathrm{NaCl}, \mathrm{KCl}$, salvadora, salvadorin, saponin, tannin, and phenol (Neihaya et al., 2020). Heteropolysaccharides has the potential to be used as a functional food ingredient. Functional food ingredients are foods that 
not only provide energy and nutrition but also has beneficial in health by modulating the gastrointestinal tract bacteria (GIT) for example prebiotic (Christwardana and Nur, 2013). Prebiotic is functional food ingredient that cannot be absorbed directly in the gastrointestinal tract, but it can be used as substrates by beneficial commensal microbiota in the digestive tract (Lestari, 2018). In addition, this material is able to suppress the growth of pathogenic bacteria (Roberfroid, 2007).

Pathogenic bacteria such as Escherichia coli (E. coli) and Salmonella Typhimurium (S. Typhimurium) are bacteria that often cause GIT disorders. These bacteria are normal microflora in the gastrointestinal because found in healthy humans GIT (Kusumo, 2012; Gut et al., 2018). These bacteria infected the human body by the consumption of contaminated water and food (Mufti et al., 2017). S. Typhimurium was able to show its virulence when the number increased to $10^{8} \mathrm{CFU} / \mathrm{ml}$ (Wotzka et al., 2017).

$E$. coli is the most common cause of diarrhea. Diarrhea cases were recorded at around 4.5 million patients with a mortality rate up to $4.76 \%$ in Indonesia (Kemenkes RI, 2018). Data from the World Health Organization (WHO) in 2017 there were 1.7 billion cases of diarrhea in children and 525,000 children under five died every year.

$S$. Typhimurium have reported as the most common cause of foodborne disease. These bacteria cause GIT disorders called salmonellosis or gastroenteritis (WHO, 2017). There are 93.8 million patients and cause 155,000 deaths per year in the world (Eng et al., 2015). Salmonellosis fever was the top 10 most common diseases in hospitalized patients in Indonesia with CFR up to 2,06\% (Afifah and Eran, 2019). Patients with immunocompromised conditions have a mortality rate more than $25 \%$ (Almeida et al., 2017). Prevalence of recurrence patients were $5 \%$ (Eng et al., 2015).

The most frequent therapy for the diseases are antibiotics such as ampicillin and chloramphenicol. Inappropriate use of antibiotics causes resistance, so it is necessary to look for other alternative therapies for prevention (Eng et al., 2015; Nurjanah et al., 2020). Prevention therapy of these GIT disorders are consuming functional foods such as prebiotic. The Neem gum compounds has the potential to be fuctional food like prebiotic that prevent GIT diseases by supress the pathogenic bacteria. As a result, the purpose of this research is to see how effective neem gum solution is at decreasing the viability of enteric pathogenic bacteria such E. coli and S. Typhimurium in vitro using MTT assay.

\section{MATERIALS AND METHODS}

\section{Materials}

Neem gum crystal purchased from Baluran (Eeast java, Indonesia), Salmonella Typhimurium (FNCC 0050), Escherichia coli (FNCC 0091), Nutrient Agar (NA), Nutrient Broth (NB), aquadest, aluminium foil, spirit, matches, alcohol, sealer, Biovision's MTT (thiazolyl blue tetrazolium bromide) assay kit (reagent and solvent), inulin (Orafit), $\mathrm{HCl}$, and anaerobic gene.

\section{Equipments}

ELISA reader (Bio Tech), incubator (ESPEC), autoclave (ALP), test tube, vortex, ose, desiccator, digital scale, microbiological safety cabinet air flow, micropipette, magnetic stirer (Lab Tech), blue and yellow tip, densitometer mcfarland (Desichek plus), laboratoy bottle.

\section{Research Design}

This study used experimental laboratories in vitro which carried out at the cellular level in the laboratory. The design of this research was the type of posttest only controls group design. It used negative control and positif control, and three groups of neem gum solutions (Concentration 5\%(w/v), 10\%(w/v), and 20\%(w/v)).

\section{Step in Research Proces}

Preparation of Bacterial Suspensions

Isolates of E. coli and S. Typhimurium from the stocks were grown back into agar media in petri dish. The bacteria then were incubated for 24 hours at $37_{-}^{\circ} \mathrm{C}$ anaerobically. After 
that, one ose was taken and suspended in NB and incubated. The bacterial suspension was diluted to $1 \times 10^{8} \mathrm{CFU} / \mathrm{ml}$ or $0.5 \mathrm{McFarland}$ (Grela et al., 2015; Ishiki et al., 2018).

Production Neem Gum Solution

Neem gum crystals were washed and dried in the sun to prevent sticking. It was ground and filtered into powder. Neem gum solution was made by mixing neem gum powder with NB media that has been dissolved in distilled water at $60^{\circ} \mathrm{C}$ to dissolve easily (Kamaraj et al., 2018). The concentration of neem gum solution was made to $5 \%(w / v), 10 \%(w / v), 20 \%$ $(\mathrm{w} / \mathrm{v})$ in $1 \mathrm{ml}$ of NB which had been prepared. The suspensions were mixed with a vortex. The solution must be sterilized in an autoclave at $121^{\circ} \mathrm{C}$ for 30 minutes (Bajury et al., 2018).

Inoculation and Bacteria Viability Counting Use the MTT assay

The bacterial suspension was inoculated as much as $50 \mu \mathrm{l}$ into each well plate and allowed to adapt for 24 hours. After that, a well containing bacteria was filled with $50 \mu \mathrm{l}$ of neem gum solution and incubated for 24 hours (Aristyawan et al., 2016). Incubation in this method is carried out anaerobically at $37^{\circ} \mathrm{C}$ (Sun et al., 2016; Hegyi et al., 2012). After incubation, $50 \mu \mathrm{l}$ of MTT reagent was added to each well and incubated for three hours until reductions (Noopan et al., 2019). The formazan crystal was dissolved using $150 \mu$ of MTT solvent after the color change from yellow to purple. The microplate was covered with aluminum foil and shaken for 15 minutes. The absorbance was then colorimetrically measured in an ELISA reader at $595 \mathrm{~nm}$ optical density (OD) (Benov, 2019; Hegyi et al., 2012). The absorbance value was entered as follows into the viability formula (Sun et al., 2016; Wati et al., 2016):

$$
\text { cell viability }=\frac{\text { Treatment absorbance }- \text { Media absorbance }}{\text { Control cells absorbance }- \text { Media absorbance }} \times 100
$$

Description :

$\%$ Cell viability

Treatment absorbance

treatment

Media absorbance

Control cells Absorbance

$=$ Percentage of live cells

= Optical density (OD) value Formazan of each sample after

$=\mathrm{OD}$ value formazan control media

$=\mathrm{OD}$ value Formazan on mean control cells

\section{Methods}

This study using MTT assay method for calculating bacterial viability. It was incubated for 24 hours in anaerobic condition prior adding the reagent and solvent of the MTT. Bacterial absorbance count on ELISA reader and then entered in the formula above.

\section{Analytical Procedure}

The data tested using Kruskal-Wallis Test to see differences in the whole group. The differences in each group were known by the Mann-Withney test. The significance value is $\mathrm{p}<0.05$.

\section{RESULT AND DISCUSSION}

In all concentrations, the viability of both bacteria exposed to neem gum solution was lower than that of the negative control or cell control. Figure 1 show us the diagram of increasing neem gum consentration causes a decrease in bacterial viability. Control cells have the largest absorbance value and the viability was $100 \%$ in both bacteria (Table 1).

Table 1 show the highest number of E.coli and S. Typhimurium absorbance was in cell control that didn't give any solution. This group act as negative controll with $100 \%$ viability. Positive control absorbance that exposed to inulin solution lower than negative control with $66.81 \%$ viability in E.coli and $69.58 \%$ in S. Typhimurium.

Viability show us more clearer how much the decreasing of bacteria number. The viability of $E$. coli bacteria in the treatment groups were $75.23 \%, 62.64 \%$, and $50.15 \%$ sorted from low concentration of neem gum solutions. The viability of $S$. Typhimurium in treatment groups were $80.73 \%, 64.66 \%$, and $52.45 \%$ sorted from low concentration of neem gum 
solution. The certain thing that we can see in the diagram in figure 1 was the decreasing of the viability due to the increasing the neem gum solution solution concentrations.

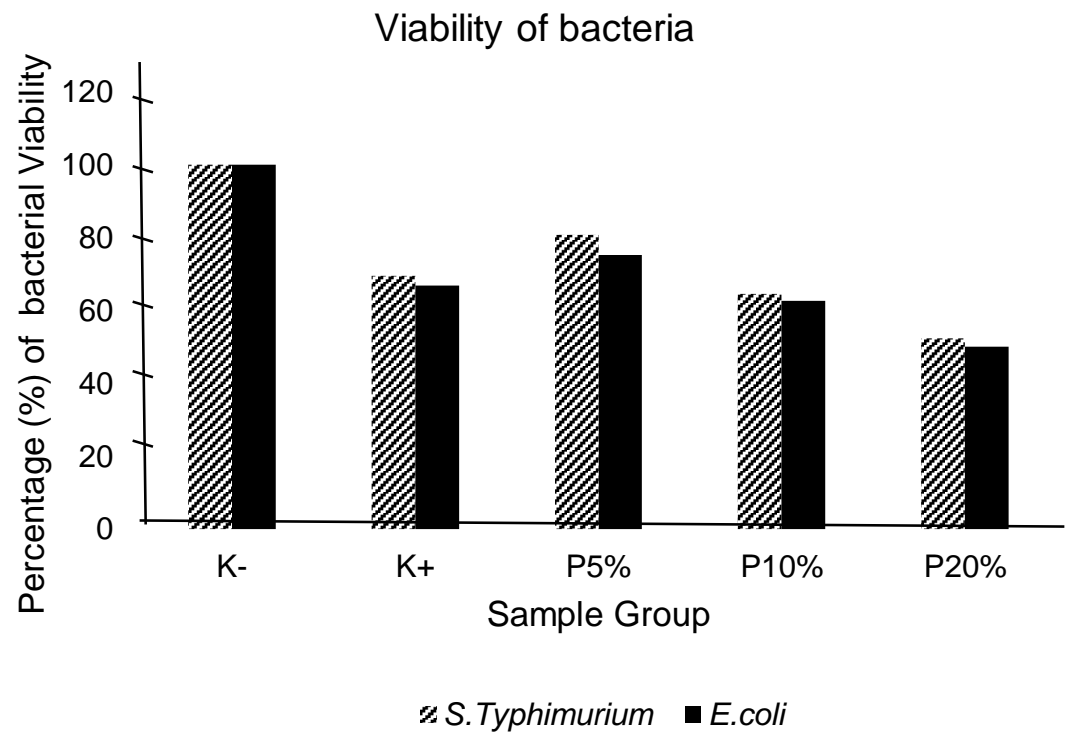

Figure 1. Viability of S.Typhimurium and E.coli bacteria

$\mathrm{K}-\quad$ : Negative control/cell control (without treatment)

$\mathrm{K}+\quad$ : Positive control (Inulin 10\% (w/v))

P $5 \%: 5 \%$ concentration of neem gum solution $(\mathrm{w} / \mathrm{v})$

P $10 \%: 10 \%$ concentration of neem gum solution (w/v)

P $20 \%: 20 \%$ concentration of neem gum solution (w/v)

Table 1. Average absorbance value and viability percentage

\begin{tabular}{|c|c|c|c|c|c|}
\hline \multirow{2}{*}{ No. } & \multirow{2}{*}{ Research group } & \multicolumn{2}{|c|}{$\overline{\mathbf{x}}$ Absorbance value } & \multicolumn{2}{|c|}{$\overline{\mathbf{x}}$ Viability (\%) } \\
\hline & & S.Typhimurium & E.coli & S.Typhimurium & E.coli \\
\hline 1 & K- & 1.011 & 0.275 & 100 & 100 \\
\hline 2 & $\mathrm{~K}_{+}$ & 0.729 & 0.211 & 69.58 & 66.81 \\
\hline 3 & P $5 \%$ & 0.833 & 0.227 & 80.73 & 75.23 \\
\hline 4 & P $10 \%$ & 0.684 & 0.203 & 64.66 & 62.64 \\
\hline 5 & P $20 \%$ & 0.571 & 0.179 & 52.45 & 50.15 \\
\hline $\begin{array}{l}\text { K - } \\
K+ \\
\text { P } 5 \% \\
\text { P } 10 \% \\
\text { P } 20 \%\end{array}$ & $\begin{array}{l}: \text { Negative co } \\
: \text { Positive cor } \\
: 5 \% \text { concen } \\
: 10 \% \text { conce } \\
: 20 \% \text { conce }\end{array}$ & $\begin{array}{l}\text { l/cell control (with } \\
\text { (Inulin } 10 \%(\mathrm{w} / \mathrm{v}) \\
\text { ion of neem gum s } \\
\text { ation of neem gum } \\
\text { ation of neem gum }\end{array}$ & $\begin{array}{l}\text { treatment) } \\
\text { ition }(w / v) \\
\text { lution }(w / v) \\
\text { lution }(w / v)\end{array}$ & & \\
\hline
\end{tabular}

The data tested in IBM SPSS Statistical Data Editor application. Differences between the two groups were tested using the Mann-Withney test. The results of data analysis for $E$. coli showed significant differences between the $\mathrm{K}$ - group with $\mathrm{K}+, \mathrm{K}$ - with all treatment groups, $\mathrm{K}+$ with P $20 \%$, P $5 \%$ with P $20 \%$, and P 10\% with P 20\% (Table 2). The same thing happened to the $S$. Typhimurium. Significant differences were also found between groups K- 
with $\mathrm{K}_{+}$, K- with all treatment groups, and P $5 \%$ with P $20 \%$ (Table 3). Further explanation will be presented in the discussion section.

Tabel 2. Statistic test result for E.coli viability

\begin{tabular}{cccccc}
\hline Kelompok Penelitian & K- & K+ & P 5\% & P 10\% & P 20\% \\
\hline K- & - & $0.005^{*}$ & $0.005^{\star}$ & $0.005^{\star}$ & $0.005^{\star}$ \\
K+ & - & - & 0.251 & 0.295 & $0.021^{\star}$ \\
P 5\% & - & - & - & 0.175 & $0.016^{\star}$ \\
P 10\% & - & - & - & - & 0.094 \\
P 20\% & - & - & - & - & - \\
\hline
\end{tabular}

Table 3. Statistic test result for S. Typhimurium viability

\begin{tabular}{cccccc}
\hline Kelompok Penelitian & K- & $K_{+}$ & $P 5 \%$ & $P 10 \%$ & $P 20 \%$ \\
\hline K- & - & $0.005^{*}$ & $0.005^{*}$ & $0.005^{*}$ & $0.005^{*}$ \\
K+ & - & - & 0.076 & 0.675 & 0.076 \\
P 5\% & - & - & - & 0.076 & $0.009^{*}$ \\
P 10\% & - & - & - & - & 0.251 \\
P 20\% & - & - & - & - & - \\
\hline
\end{tabular}

\begin{tabular}{ll}
\hline $\mathrm{K}-$ & $:$ Negative control/cell control (without treatment) \\
$\mathrm{K}+$ & $:$ Positive control (Inulin $10 \%(\mathrm{w} / \mathrm{v})$ ) \\
P $5 \%$ & $: 5 \%$ concentration of neem gum solution (w/v) \\
P $10 \%$ & $: 10 \%$ concentration of neem gum solution $(\mathrm{w} / \mathrm{v})$ \\
P $20 \%$ & $: 20 \%$ concentration of neem gum solution $(\mathrm{w} / \mathrm{v})$ \\
* significantly different
\end{tabular}

The results showed that the viability of $E$. coli and $S$. Typhimurium bacteria had the same pattern due to exposure of neem gum solutions. The treatment groups of these bacteria that were exposed by neem gum solution was lower than the negative control. Negative control was used as a benchmark for the research group because these bacteria were grown on culture media only. The negative control had the highest absorbance value, and the viability indicated that the inoculated bacteria were alive as a whole. The positive control viability is also lower than the negative control. It is because the solution contains inulin that has complex carbohydrates in the form of fructooligosaccharide. Inulin can not be fermented by these two pathogenic bacteria.

Viability of both bacteria species treated with neem gum solution decreased as the concentration of the solution increased (Figure 1). The lowest bacterial viability was found in exposure to $20 \%$ neem gum solution. Both of these bacteria belong to the gram negative species. Neem gum was effective to inhibit gram negative bacteria, $E$. coli, at a maximum concentration of $20 \%$ (Samrot et al., 2020). This study used a high level of accuracy method. The decrease of viability has been seen at the lower concentration of neem gum solution.

Neem gum solution can decreases the viability of $E$. coli and S. Typhimurium due to several possible factors. The main factor is disruption from the heteropolysaccharide of neem gum to their nutrition. These bacteria can not ferment heteropolysaccharide in the neem gum 
solution. This ability requires the presence of extracellular enzymes that are able to break the glycan bonds. S. Typhimurium and E. coli do not have this kind of enzyme. This substrate will be utilized by lactic acid bacteria such as Bifidobacterium longum and Lactobacillus $s p$. that have galactosidase enzymes, arabinose enzymes, pectinase enzymes, glucosidase enzymes and cellulose (Utama et al., 2018). The largest monosaccharides in neem gum are galactose and arabinose (Moniem et al., 2018). Galactose and arabinose unable to be fermented by $E$. coli and S. Typhimurium. The evidence showed that galactose has the ability to inhibit the growth of pathogenic bacteria by absorb the bacteria nutrient (Sari et al., 2020). Hence, bacteria metabolism disturbed. Heteropolysaccharide with all the monosaccaride compounds can damage the structure of the bacterial cell wall and membrane. It works by penetrating the bacterial cell membrane and damaging its integrity (Zhang et al., 2017; Wang et al., 2019). It enter the cell and breaking down DNA into small fragments. DNA is known to have an important role in cell life, so it will damage cell life (Rjeibi et al., 2020).

Neem gum contains other active compounds such as $\mathrm{NaCl}, \mathrm{KCl}$, salvadora, salvadorin, saponins, and tannins (Neihaya et al., 2020). Chloride in $\mathrm{NaCl}$ and $\mathrm{KCl}$ causes the killing of bacteria because of the acidic conditions they cause. Salvadora and salvadorin are the same compounds found in the stem of the miswak. These two active compounds have been shown to be able to inhibit bacterial growth (Darout, 2015; Nadir et al., 2020). Saponins cause bacterial cell lysis by increasing the permeability of the bacterial cell membrane. Meanwhile, tannins are able to coagulate the protoplasm of bacteria so that their growth becomes inhibited (Halimah et al., 2019). Phenol is also contained in neem gum. Phenol can damage bacterial membranes and denature cell proteins which are important systems in bacterial cells (Septiani et al., 2017; Marfuah et al., 2018). Low pH also affects the life of pathogenic bacteria. Neem gum solution is known to have a fairly acidic $\mathrm{pH}$ reaching 4.2-4.8 (Moniem et al., 2018). The higher the concentration of the solution, the lower the $\mathrm{pH}$. The low $\mathrm{pH}$ causes the environmental conditions of the bacteria to be disturbed, causing bacterial cell lysis.

Beside knowing the possible factors that cause a decrease in the viability of these two pathogenic bacteria, data was analyzed to see the differences in the research groups. The results of the difference test between the negative control group and the positive control group showed a significant difference between the two bacteria. This difference was caused because the bacteria in the positive control group were exposed to inulin solution while the negative control group had no exposure. Inulin is a commercial prebiotic product that has been widely used. The structure of inulin is a complex carbohydrate in the form of fructooligosaccharides (Farias et al., 2019). This carbohydrate also has glycan bonds which are not able to be broken down by these pathogenic bacteria.

Different test in the negative control group with all treatment groups resulted in significant differences for E. coli and S. Typhimurium. The negative control was bacteria that cultured on broth media only, while the treatment group was given by neem gum solution with three different concentrations. Neem gum solution contains various complex polysaccharide that can reduce the viability of $E$. coli and $S$. Typhimurium bacteria. Polysaccharide becomes a substrate that cannot be fermented, interferes with bacterial nutrient uptake, lowers environmental $\mathrm{pH}$, increases cell membrane permeability, damages cell wall and membrane integrity, damages DNA, and coagulates bacterial cell protoplasm. Therefore, pathogenic bacteria exposed to neem gum solution had a lower viability than the negative control.

The positive control group only has a significant difference with P $20 \%$ in E. coli while in S. Typhimurium there was no significant difference in all treatment groups. Significant differences in E. coli can be caused by different bacterial structures so that bacteria are more sensitive to the content in the neem gum solution than $S$. Typhimurium. Nothing difference between the groups because both inulin and neem gum is a non-starch complex polysaccharide that is soluble in water and E. coli and S. Typhimurium bacteria were also unable to utilize these two materials as substrates. This situation causes disruption to the life of these bacteria which ultimately reduces their viability. The concentration of the positive control also took the mean of the treatment group, which was $10 \%$. This causes the effect of the content on the viability of the three solution concentrations not much different. 
Significant differences were found in P $5 \%$ with P $20 \%$ groups in both bacteria and P $10 \%$ with P $20 \%$ in E. coli only. P $10 \%$ is the middle concentration of the treatment group. Concentration gave a different effect on bacterial viability seen between $P 5 \%$ and $P 20 \%$. The concentration is directly proportional to the content of neem gum carried. Hence, the effect of neem gum solution increases as the concentration is added. The results showed that the highest concentration resulted in the lowest viability.

The result shows that neem gum solution can reduce the viability of $E$. coli and S.Typhimurium. The factors were caused by the heteropolysaccharide and bioactive compounds. Heteropolysaccharide cannot be fermented and it interferes bacterial nutrient uptake. It also makes the environmental $\mathrm{pH}$ low, increases cell membrane permeability, damages cell wall and membrane integrity, damages DNA, and coagulates bacterial cell protoplasm.

\section{CONCLUSIONS}

Based on the results of this study, it was concluded that the gum neem solution was effective in reducing the viability of $E$. coli and $S$. Typhimurium bacteria in vitro.

\section{ACKNOWLEDGEMENTS}

Thank you to the lecturers, the neem gum research team, and everyone who contributed with this research.

\section{REFERENCES}

Afifah, Nur Riezqiyah \& Eram Tunggul Pawenang. (2019). The incidence of typhoid fever at the age of 15-44 years. Higeia Journal of Public Health Research and Development. 3(2): 263-273.

Almeida, F., A. A. Seribelli, P. da Silva, M. I. C. Medeiros, D. dos Prazeres Rodrigues, C. G. Moreira, M. W. Allard, \& J. P. Falcão. (2017). Multilocus Sequence Typing of Salmonella Typhimurium Reveals The Presence of The Highly Invasive St313 in Brazil. Infection, Genetics and Evolution, 51, 41-44.

Aristyawan, A. D., N. E. Sugijanto, \& Suciati (2017).Antibacterial Potential of The Ethanolic Extract of The Agelas cavernosa Sponge. Indonesian Journal of Pharmacy and Pharmaceutical Sciences, 3(1), 32-38.

Bajury, D. M., S. M. Nashri, P. King Jie Hung, \& S. R. Sarbini. (2018). Evaluation of Potential Prebiotics: A Review. Food Reviews International, 34(7), 639-664.

Benov, L. (2019). Effect Of Growth Media on The MTT Colorimetric Assay in Bacteria. Journal Plos One, 14(8), 1-15.

Christwardana, M. \& M. M. A. Nur. (2013). Spirulina Platensis: Its Potential As A Functional Food Ingredient. Jurnal Aplikasi Teknologi Pangan, 2(1), 1-4.

Darout, I. A. (2015). Review on Chemical and Biologically Active Components of The Toothbrush Tree (Salvadora persica). European Journal of Pharmaceutical and Medical Research, 2(6), 1-7.

Eng, S. K., P. Pusparajah, N. S. Ab Mutalib, H. L. Ser, K. G. Chan, \& L. H. Lee. (2015). Salmonella: A Review on Pathogenesis, Epidemiology and Antibiotic Resistance. Frontiers in Life Science, 8(3), 284-293.

Farias, David de Paulo, Fábio Fernandes de Araújo, Iramaia Angélica Neri-Numa, \& Glaucia Maria Pastore. (2019). Prebiotics: Trends in Food, Health and Technological Applications. Trends in Food Science \& Technology, 23-35.

Grela, E., A. Ząbek, \& A. Grabowiecka. (2015). Interferences in The Optimization of The Mtt Assay for Viability Estimation of Proteus Mirabilis. Avicenna Journal of Medical Biotechnology, 7(4),159-167. 
Gut, A. M., T. Vasiljevic, T. Yeager, \& O. N. Donkor. (2018). Salmonella Infection Prevention and Treatment by Antibiotics and Probiotic Yeasts: A Review. Microbiology Society, 164(11), 1327-1344.

Halimah, H., D. M. Suci, \& I. Wijayanti. (2019). Study on The Potential Use of Noni Leaves (Morinda citrifolia L.) As Antibacterial Ingredients for Escherichia coli and Salmonella Typhimurium. Journal of Agricultural Science Indonesian, 24(1), 58-64.

Hegyi, F., Z. Zalán, \& A. Halász. (2012). Improved 3-(4,5-Dimethylthiazol-2-YI) -2,5-Diphenyl Tetrazolium Bromide (Mtt) Colorimetric Assay For Measuring The Viability Of Lactic Acid Bacteria. Acta Alimentaria, 41(4), 506-512.

Ishiki, K., D. Q. Nguyen, A. Morishita, H. Shiigi, \& T. Nagaoka. (2018). Electrochemical Detection of Viable Bacterial Cells Using A Tetrazolium Salt. Analytical Chemistry. Doi: 90(18):10903-10909.

Kamaraj, C., P. R. Gandhi, G. Elango, S. Karthi, I. M. Chung, \& G. Rajakumar. (2018). Novel and Environmental Friendly Approach; Impact Of Neem (Azadirachta indica) Gum Nano Formulation (Ngnf) on Helicoverpa armigera (Hub.) and Spodoptera litura (Fab.). International Journal of Biological Macromolecules, 107(PartA), 59-69.

Kemenkes RI. (2018). RI Health Profile. Jakarta : Kemenkes RI.

Kumar, V. S. \& V. Navaratnam. (2013). Neem (Azadirachta indica): prehistory to contemporary medicinal uses to humankind. Asian Pasific Journal of Tropical Biomedicine, 3(7), 505-514.

Kusumo, P. D. (2012). Colonization of The Normal Microbiota And Its Effect on The Development of The Neonatal Immune System. Widya Medical Journal, 29(320):55-63.

Lestari, L.A. \& Helmyati, S.,. (2018). The Role of Probiotics in the Field of Nutrition and Health. Gadjah Mada University PRESS.

Marfuah, I., Dewi, E.N. \& Rianingsih. (2018). Study of the Potential of Sea Grape Extract (Caulerpa racemosa) As Antibacterial Against Escherichia coli and Staphylococcus aureus. Journal of Fishery Products Processing and Biotechnology, 7(1):7-14.

Moniem, M. E., E. A. Hassan, \& M. E. Osman. (2018). Characterization and Rheological Behavior of Neem Gum (Azadirachta indica). International Journal of Chemical Studies 2018; 6(3):1977-1981.

Mufti, N., Bahar, E. \& Arisanti, D.,. (2017). In Vitro Inhibitory Test of Sawo Leaf Extract against Escherichia coli Bacteria. Andalas Health Journal, 6(2):289-294.

Nadir, A., A. A. Farrag, E. A. Helmy, \& A. S. Ismail. (2020). Miswak (salvadora persica) Roots as Antimicrobial and A Potential Bioactive Component. Middle East Journal of Applied Sciences, 10(1):50-56.

Neihaya, Zahraa, \& Kadhem. (2020). Antibacterial and Anti-Biofilm Activities of Neem Gum (Azadirachta indica) and Arabic Gum (Acacia senegal) Extracts on Human Pathogenic Bacteria. Al-Kufa University Journal of Biology, 12(2):80-90.

Noopan, S., P. Unchui, S. Techotinnakorn, \& R. S. Ampornaramveth. (2019). Plasma Sterilization Effectively Reduces Bacterial Contamination in Dental Unit Waterlines. International Journal of Dentistry, 4,1-6.

Nurjanah, G.S., Cahyadi, A.I. and Windria, S. (2020). Kajian Pustaka: Escherichia coli Resistance to Various Antibiotics in Animals and Humans. Indonesia Medicus Veterinus, $9(6): 970-983$

Nussinovitch. (2010). A Plant Gum Exudates of the World: Sources, Distribution, Properties, Applications. New York: CRC. Plant Gum Exudates of the World: Sources, Distribution, Properties, and Applications.

Pankaj, S., Lokeshwar, T., Mukesh, B. \& Vishnu, B. (2011). Review on neem (Azadirachta indica): thousand problems one solution. International research journal of pharmacy, 2(12):7-102.

Prianto, A. H., N. Budiawan, Y. Yulizar, \& P. Simanjuntak. (2019). The synergy effect of azadirachtin and minor components of neem seed oil on antifeedant activity of spodoptera litura. Spice and Medicinal Plant Research Bulletin, 30(1):27-34.

Rjeibi, I., Zaabi, R. \& Jouida, W. (2020). Characterization of Polysaccharides Extracted from Pulps and Seeds of Crataegus azarolus L. var. aronia: Preliminary Structure, 
Antioxidant, Antibacterial, $\alpha$-Amylase, and Acetylcholinesterase Inhibition Properties. Oxidative medicine and cellular longevity, 2020:1-11.

Roberfroid, M. (2007). Prebiotics: The Concept Revisited 1 , 2. The Journal of Nutrition. 137(3):830-837.

Samrot, A. V, J. L. A. Angalene, S. M. Roshini, S. M. Stefi, R. Preethi, P. Raji, M. K. A, \& S. Kumar S. (2020). Purification, Characterization and Exploitation of Azadirachta indica Gum For The Production of Drug Loaded Nanocarrier. Materials Research Express, 7(5), 1-13.

Sari, R.S., A. Baehaki, S.D. Lestari, E. Arafah, \& Guttifera. (2020). Inhibitory of Pathogenic Bacteria in Processed Fishery Products, Bacteria For Fishery Products. Indonesian Fishery Product Processing Society, 23(3):542-547.

Septiani, S., Dewi, E.N. \& Wijayanti, I. (2017). Antibacterial Activity of Seagrass Extract (Cymodocea rotundata) Against Staphylococcus aureus and Escherichia coli. Saintek Perikanan: Indonesian Journal of Fisheries Science and Technology, 13(1):1-6

Sun, M., Z. Zhou, J. Dong, J. Zhang, Y. Xia, \& R. Shu. (2016). Antibacterial and Aantibiofilm Activities of Docosahexaenoic Acid (Dha) and Eicosapentaenoic Acid (Epa) Against Periodontopathic Bacteria. Microbial Pathogenesis, 99,196-203.

Utama, C. S., Zuprizal, C. Hanim, \& Wihandoyo. (2018). Isolation and Identification of Cellulolytic Lactic Acid Bacteria From Fermented Cabbage Juice. Food Technology Application Journal, 7(1), 1-6.

Wang, Z., R. Xue, J. Cui, J. Wang, W. Fan, H. Zhang, \& X. Zhan. (2019). Antibacterial Activity Of A Polysaccharide Produced From Chaetomium Globosum CGMCC 6882. International Journal of Biological Macromolecule, 125, 376-382.

Wati, E. M., A. R. Puspaningtyas, \& D. A. Pangaribowo. (2016). Toxicity and Proliferation Test (1-(4-nitrobenzoiloksi-metil)-5-fluorourasil mcf-7 methyl) -5-fluorouracil ) on Breast Cancer Cells Mcf-7 ). Health Library, 4(3), 484-488.

World Health Organization. (2017). Diarrhoeal disease. Viewed 14 Juni 2021, <https://www.who.int/news-room/fact-sheets/detail/diarrhoeal-disease>

Wotzka, S. Y., B. D. Nguyen, \& W. Hardt. (2017). Review Salmonella Typhimurium Diarrhea Reveals Basic Principles of Enteropathogen Infection and Disease-Promoted DNA Exchange. Cell Host and Microbe, 21(4), 443-454.

Zhang, Y., Y. T. Wu, W. Zheng, X. X. Han, Y. H. Jiang, P. L. Hu, Z. X. Tang, \& L. E. Shi. (2017). The Antibacterial Activity and Antibacterial Mechanism of A Polysaccharide From Cordyceps cicadae. Journal of Functional Foods, 38, 273-279. 